\title{
Gamma-Ray-Induced Polymerization of Mixed Liposomes Consisting of 2,4-Octadecadienoyl Groups of Phospholipids and Unpolymerizable Components
}

\author{
Kazuhiro AKaMA*1†, Kouji AWAI*1, Yoshihiro YANo*1, Satoru TOKUYAMA ${ }^{* 1+}$, \\ Yóshio NAKANo*1, Fumio HosoI ${ }^{* 2 \ddagger}$ and Hideki OMICHI ${ }^{* 2 \#}$ \\ *1 Tsukuba Research Laboratory, NOF Corporation \\ (5-10, Tokodai, Tsukuba-shi, Ibaraki-ken 300-2635) \\ *2 Takasaki Radiation Chemistry Research Establishment, Japan Atomic Energy Research Institute \\ (1233, Watanuki-machi, Takasaki-shi, Gunma-ken 370-1207)
}

\begin{abstract}
We studied the $\gamma$-ray-induced polymerization of two mixed-liposome systems containing 1,2-bis-[(2E,4E)-octadecadienoyl]-sn-glycero-3-phosphocholine (DODPC) to clarify its mechanism ; (a) containing DODPC and 1,2-dipalmitoyl-sn-glycero-3-phosphocholine (DPPC), or DODPC/DPPC liposome, and (b) containing DODPC, DPPC, Cholesterol (Chol), and stearic acid (SA), or DODPC/ $\mathrm{DPPC} / \mathrm{Chol} / \mathrm{SA}$ liposomes was carried out. For each system, various molar ratios of DODPC/DPPC were studied. For DODPC/DPPC/Chol/SA liposomes, the molar ratio of phospholipid/Chol/SA was 7/7/2. Liposomes were prepared by extrusion through a $0.2-\mu \mathrm{m}$-pore polycarbonate filter and polymerized by $\gamma$ irradiation at a dose rate of $3.3 \mathrm{kGy} / \mathrm{h}$ at $4{ }^{\circ} \mathrm{C}$. Polymerization rate increased when DODPC/DPPC was $5 / 5$ in DODPC/DPPC liposomes and when it was 9/1, 8/2, 7/3, and 5/5 in DODPC/DPPC/Chol/SA liposomes. The degree of polymerization at molar ratio $5 / 5$ for each mixed-liposome system significantly increased compared with that of DODPC liposomes containing no DPPC. For polymerized mixed liposomes stability, mean diameter after one freeze-thaw cycle remained unchanged for molar ratios from 10/0 to $8 / 2$ of either DODPC/DPPC or DODPC/DPPC/Chol/SA liposomes. $\gamma$-Ray-induced polymerization of each mixed-liposome system was analyzed using kinetic treatment of polymerization. Although the rate of polymerization for either systems differed from that of DODPC liposomes, the polymerization mechanism was the same. Immiscibility between DODPC and unpolymerizable components was estimated based on the kinetic data of polymerization. Hydrophobic interactions of DPPC and/or Chol with DODPC significantly affected the conformation of DODPC, which rearranges into an easily polymerizable conformation. The rate and degree of polymerization thus increased.
\end{abstract}

Key words : polymerizable phospholipid, liposome, $\gamma$-ray, freeze-thaw, mixed-lipids

\section{Introduction}

Application of liposomes as carriers for drug delivery systems and artificial red cell has received much attention because liposomes can encapsulate drugs, such as anti-cancer agents, proteins, and various bioactive materials ${ }^{1)}$. However, pure liposomes such as DPPC have low stability in the bloodstream, resulting in leakage of inner substances and in aggregation ${ }^{2,3)}$. One well-known

Corresponding authors : Kazuhiro AKama and Yoshio NAKano

$\dagger \quad$ Present address : Medical Materials Business Dept., Oleo \& Speciality Chemicals Division, NOF Corporation (4-20-3, Ebisu, Shibuya-ku, Tokyo 150-6019)

† Present address : Oleochemicals Research Laboratory, NOF Corporation (1-56, Ohama-cho, Amagasaki, Hyogo 660-0095)

‡ Deceased March 13, 1998 .

\# Current address : Japan Atomic Energy Research Institute Washington Office (1825 K Street, N.W., Suite 508, Washington, D.C. 20006-1202, U.S.A.) 
technique for stabilizing liposome membranes is to use polymerizable phospholipids ${ }^{4) \sim 6)}$.

Among the various methods developed to polymerize liposome membranes, $\gamma$-ray- induced polymerization is effective for drugs encapsulated in polymerizable liposomes because the method has no residual initiators, less degradation and denaturation of encapsulated substances, and a high conversion yield, and also can polymerize liposomes at temperatures as low as $4{ }^{\circ} \mathrm{C}^{7) \sim 9}$.

We previously developed a liposome type of artificial red blood cells, which we call artificial red cells (ARC), that encapsulate hemoglobin, using a mixture of 1,2-bis-[(2E,4E)-octadecadienoyl]-snglycero-3-phosphocholine (DODPC, Scheme I), cholesterol (Chol), and fatty acids. Even after repeated freeze-thaw cycles, the $\gamma$-ray-polymerized membranes of ARC showed no change in diameter and no leakage of hemoglobin ${ }^{9) \sim 11}$. Moreover, this polymerized ARC is stable in the bloodstream (i.e., no aggregation, toxicity, or side effects) $)^{9,10), 12)}$.

Polymerized DODPC liposomes are extremely stable due to the cross-linking polymerization of 2,4-octadecadienoly groups of DODPC. Polymerized ARC whose membrane comprises DODPC, Chol, and fatty acid is also sufficiently stable in vivo. When ARC was intravenously injected into rats, the ARC circulated in the bloodstream and then finally trapped in the liver and spleen ${ }^{13}$. The weight of liver and spleen increased because the polymerized liposomes that contain poly-phospholipids have a low bio-degradation. To reduce the poly-phospholipid content of the membranes, we also previously developed an ARC system composed of a mixed liposome ; DODPC, DPPC (1,2Dipalmitoyl-sn-glycero-3-phosphocholine), Chol, and stearic acid (SA). The stability of this system during repeated freeze-thaw cycles and in vivo is the same as an ARC system composed of DODPC, Chol, and fatty acid.

Despite the attention given to the stability of DODPC liposomes and their polymerization

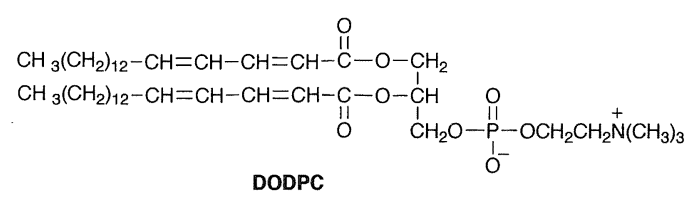

Scheme I behavior $^{8,11)}$, the mechanism of polymerization induced by $\gamma$-irradiation has only been reported by Tsuchida et al. ${ }^{14}$. We recently did a kinetic study of $\gamma$-ray-induced polymerization of pure DODPC liposomes ${ }^{7,15), 16)}$, and found that such polymerization allows selective polymerization between the 1and 2-acyl chain ${ }^{15}$. However, the polymerization mechanism is not yet clear for the mixed-lipids system in ARC that consists of DODPC and unpolymerizable components, such as DPPC, Chol, and fatty acids. In this study, we describe (a) $\gamma$-ray-induced polymerization of two DODPC mixed-liposome systems, DODPC/DPPC and DODPC/DPPC/Chol/SA, for various molar ratios of DODPC/DPPC to reveal the polymerization mechanism of a mixed-liposome system and (b) the stability of polymerized liposomes during freeze-thaw cycles.

\section{Experimental}

\section{$2 \cdot 1$ Materials}

Unless otherwise stated, all reagents and chemicals were obtained commercially and used without further purification. Cholesterol and stearic acid were purchased from Wako Chemical Co., Ltd. The 1,2-dipalmitoyl-sn-glycero-3-phosphocholine was manufactured by NOF Corporation, and 1,2-bis-[(2E,4E)-octadecadienoyl]-snglycero-3-phosphocholine was synthesized as described previously ${ }^{17)}$. The purification of the phospholipids was confirmed by thin layer chromatography (TLC) in chloroform/methanol/water (65/25/4 by volume) before use. The TLC revealed that each phospholipid showed a single spot whose $R_{f}$ (rate of flow) value was around $0.2 \sim 0.3$. Ultrapure water was further purified by using a TORAYPURE LV-08 system (TORAY Co., Ltd.).

\section{$\mathbf{2 \cdot 2}$ Preparation of Mixed-Lipids}

The DODPC and DPPC were combined to a total of $10 \mathrm{~g}$ at various molar ratios ; 10/0, 9/1, 8/2, $7 / 3$, or $5 / 5$ (hereafter the respective liposomes are called 10/0 DODPC/DPPC, 9/1 DODPC/DPPC, etc.). The DODPC, DPPC, Chol, and SA were combined to total of $10 \mathrm{~g}$ at various DODPC/ DPPC molar ratios of $10 / 0,9 / 1,8 / 2,7 / 3$, or $5 / 5$ and at phospholipids/Chol/SA molar ratio of $7 / 7 / 2$ (hereafter the respective liposomes are called 10/0 DODPC/DPPC/Chol/SA, 9/1 DODPC/ DPPC/ $\mathrm{Chol} / \mathrm{SA}$, etc. $)$. Each lipid mixture $(10 \mathrm{~g})$ was then 
dissolved in $500 \mathrm{~mL}$ of benzene that was below 50 ${ }^{\circ} \mathrm{C}$. The mixture was then frozen in a liquidnitrogen bath and lyophilized in a freeze-drier (Freezemobile $25 \mathrm{EL}$, Virtis Co., Inc.) for $48 \mathrm{~h}$.

\subsection{Preparation of Liposomes}

All liposomes in this study were prepared by using an extrusion method. The mixed lipids $(2 \mathrm{~g})$ were placed in a polyethylene bag $(100 \times 150 \mathrm{~cm})$ and hydrated with $20 \mathrm{~mL}$ of ultra-pure water. The resulting dispersions were kept at above $40{ }^{\circ} \mathrm{C}$. The dispersions were homogenized for $20 \mathrm{~min}$ by using a Stomacher (UAC HOUSE, Model : BA6020, SEWARD MEDICAL). The solutions were extruded stepwise (by using an Extruder, Lipex Biomembranes Inc.) through polycarbonate filters whose respective pore sizes were $1,0.4$, and 0.2 $\mu \mathrm{m}$. To narrow the diameter distribution of the liposomes, the liposome solution was passed three times through $0.2-\mu \mathrm{m}$-pore polycarbonate filters. The liposome solution was adjusted to ca. $2 \mathrm{wt} \%$ lipid concentration by dilution with ultra-pure water.

\subsection{Polymerization of Liposomes}

About $40 \mathrm{~mL}$ of the $2 \mathrm{wt} \%$ liposome solution was placed into a $50-\mathrm{mL}$ glass vial, which was then sealed with an aluminum-covered rubber cap. The solution was bubbled with argon for $30 \mathrm{~min}$ at room temperature. Five milliliters of liposome solution was transferred (by using a $10-\mathrm{mL}$ injection syringe) to a $10-\mathrm{mL}$ sealed glass vial that contained an argon atmosphere. The solution was then stirred magnetically at $4{ }^{\circ} \mathrm{C}$ and irradiated with $\gamma$-rays from a ${ }^{60} \mathrm{Co}$ source $(25000 \mathrm{Ci})$. A dose rate of $3.3 \mathrm{kGy} / \mathrm{h}$ for the $\gamma$-rays was attained by adjusting the distance between the ${ }^{60} \mathrm{Co}$ source and the solution. Fresh liposome solutions were prepared for each measurement of the polymerization conversion and molecular weight.

\subsection{Measurement of Diameter}

To determine the mean diameter of the liposomes, we measured the intensity of scatteredlight of the liposomes by using a scattered-light particle-sizer instrument. Three milliliters of ultrapure water was filtered through a $0.2-\mu \mathrm{m}$-pore filter by using a syringe and then placed in a $1-\mathrm{cm}$ quartz cuvette equipped with a Teflon stopper. The liposome solution (ca. $1 \mathrm{~mL}$ ) was then added, and then mixed until the solution was a homogeneous dispersion. The mean diameter of the liposomes was determined by using a Nicomp
model-370HPL particle sizer (Pacific Scientific) and a $\mathrm{He}-\mathrm{Ne}$ laser to first record the intensity of scattered-light and then to convert it a gaussianmode size distribution. The standard deviation (SD) of the mean diameter was also recorded at the scattered-light intensity.

\subsection{Measurement of Polymerization Con- version}

To determine the polymerization conversion after the liposomes were irradiated, we measured the decrease in the chromophores, based on the diene group of DODPC. The monomeric liposome solutions (5-10 $\mu \mathrm{L}$ of DODPC/DPPC liposomes or $10-20 \mu \mathrm{L}$ of DODPC/DPPC/Chol/SA liposomes) were diluted with $3 \mathrm{~mL}$ of ultra-pure water by using a transfer pipette. The solution was homogeneously dispersed and transferred to a 1$\mathrm{cm}$ quartz cell. By using a UV spectrometer (UV240, Shimadzu Corporation), the liposome solutions were measured at room temperature for the absorption of each liposome at the absorption maximum $\left(\lambda_{\max }\right)$ at $254 \mathrm{~nm}$, based on the chromophore of the diene group. The irradiated liposome solutions were similarly measured. A polymerization yield of $100 \%$ was obtained by irradiating the diluted monomeric liposome by using a UV lamp (MODEL ENF-260C/J, Spectronics Corporation) at $254 \mathrm{~nm}$ until absorption at $\lambda_{\max }$ disappeared. The polymerization conversions were calculated from the difference between the absorption at $\lambda_{\max }$ of the irradiated liposome solution and that of the monomeric liposome as follows :

Polymerization conversion $(\%)=\left(\mathrm{A}_{\mathrm{I}}-\mathrm{A}_{\mathrm{T}}\right) /\left(\mathrm{A}_{\mathrm{I}}\right.$ $\left.-\mathrm{A}_{0}\right) \times 100$

where $A_{T}$ is the absorption intensity at $\lambda_{\max }$ after irradiation, $A_{I}$ is the absorption intensity at $\lambda_{\max }$ before irradiation, and $\mathrm{A}_{0}$ is the absorption intensity for UV-induced $100 \%$ polymerization.

\subsection{Molecular Weight Measurement}

Polymerized DODPC (poly-phospholipids) in the liposome after $\gamma$-irradiation is insoluble in any organic solvent because the poly-phospholipids are cross-linking polymers. We therefore determined the molecular weights of the poly-phospholipids by measuring the octadecadienoic acid polymer obtained from hydrolysis of the irradiated liposomes. Five milliliters of $2 \mathrm{~N}-\mathrm{NaOH}$ was added to 5 $\mathrm{mL}$ of irradiated liposomes and kept at $70{ }^{\circ} \mathrm{C}$ for 24 $\mathrm{h}$. The resulting reaction mixture was then cooled 
to room temperature, neutralized with $5 \mathrm{~mL}$ of $2 \mathrm{~N}$ $\mathrm{HCl}$, and further cooled to $4{ }^{\circ} \mathrm{C}$. The resulting precipitate was filtered through a $5 \mathrm{G}$ glass filter, rinsed with ultra-pure water, and dried in vacuo for $12 \mathrm{~h}$. The obtained solids $(10 \mathrm{mg})$ were dissolved in $5 \mathrm{~mL}$ of tetrahydrofuran (THF). The number-average molecular weights $\left(M_{n}\right)$ of the solutions containing octadecadienoic acid polymer $(10 \mu \mathrm{L})$ were measured by using gel permeation chromatography (GPC) with THF as eluent at 4 ${ }^{\circ} \mathrm{C}$. Two systems of columns were used : for lower molecular weight, we used a HLC-802UR system (Toyo Soda Co., Ltd.) equipped with a column of $2500 \mathrm{H}_{\mathrm{XL}}+\mathrm{G} 2000 \mathrm{H}_{\mathrm{XL}}$ whose molecular-weight range was $3 \times 10^{2} \sim 3.5 \times 10^{4}$, and for higher molecular weight, we used a HLC-802A system (Toyo Soda Co., Ltd.) equipped with a column of $\mathrm{G} 5000 \mathrm{H}_{\mathrm{XL}}+\mathrm{G} 3000 \mathrm{H}_{\mathrm{XL}}$ whose range was $1 \times 10^{3} \sim$ $2 \times 10^{6}$. The $\mathrm{M}_{\mathrm{n}}$ was calculated from the calibration curve by using standard polystyrenes on the HLC$802 \mathrm{~A}$ system. The degree of polymerization $\left(\mathrm{P}_{\mathrm{n}}\right)$ was determined from the $M_{n}$ of 2,4-octadecadienoic acid, which was 557 based on the curve of standard polystyrene using the HLC-802UR system.

\section{$2 \cdot 8$ Physical Stability of Liposomes} (Freeze-Thaw Test)

A freeze-thaw test was used to measure the stability of the liposomes. First, the irradiated liposome solution $(2 \mathrm{~mL})$ was transferred to a $10-$ $\mathrm{mL}$ sample tube and placed in liquid nitrogen for 5 min. Then the resulting frozen liposome solution was thawed gradually at room temperature. After the sample was completely thawed, the average diameter of the liposomes was measured by using the same particle sizer instrument previously described (see Experimental section, Measurement of Diameter). The mean diameter and SD measured before freezing were compared with those measured after one freeze-thaw cycle.

\section{Results}

\section{$3 \cdot 1$ Polymerization of Liposomes}

Figure 1a shows the curve of the polymerization conversion of the DODPC/DPPC liposomes. For every molar ratio of DODPC/DPPC system, the polymerization conversions rapidly increased to $50 \%$ within ca. $2 \mathrm{~h}$, and then increased more slowly with further irradiation. The conversions of the $7 / 3,8 / 2$ and $9 / 1$ DODPC/DPPC liposomes
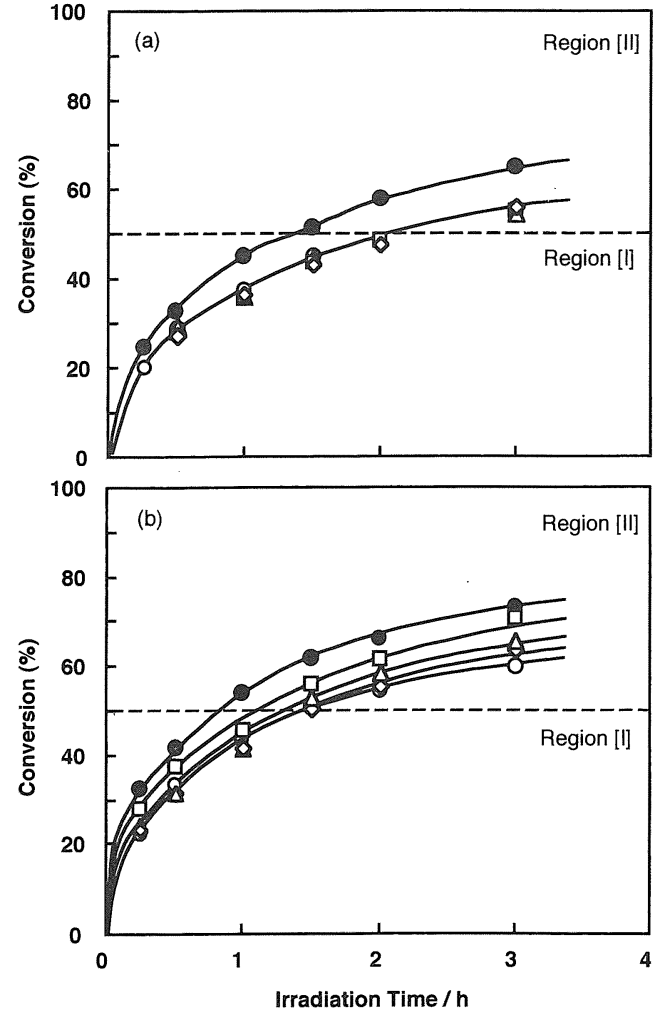

Fig. 1 Effect of the Compositions of DODPC/DPPC on the Polymerization Conversion of the Liposomes. The Liposomes were Irradiated by $\gamma$-Ray at a Dose Rate of $3.3 \mathrm{kGy} / \mathrm{h}$ at $4{ }^{\circ} \mathrm{C}$. (a) DODPC/DPPC liposomes, (b) DODPC/DPPC/ Chol/SA Liposomes. DODPC/DPPC Molar Ratio : $10 / 0(\bigcirc), 9 / 1(\diamond), 8 / 2(\triangle), 7 / 3(\square)$, and $5 / 5$ (O).

were similar to that of the DODPC liposomes that contain no DPPC. For 5/5 DODPC/DPPC, however, the polymerization conversion was about $10 \%$ greater than that for other molar ratios of the DODPC/DPPC liposome at $3 \mathrm{~h}$. Figure 2a shows the $M_{n}$ of poly-2,4-octadecadienoic acids that were obtained by hydrolysis of irradiated $10 / 0$ and $5 / 5$ DODPC/DPPC. For both molar ratios (10/0 and $5 / 5$ ), the $M_{n}$ of the liposomes decreased with increasing irradiation time. The degree of polymerization for 5/5 DODPC/DPPC was about $10 \%$ greater than that for $10 / 0$ DODPC/DPPC. The degree of polymerization of $10 / 0$ and $5 / 5$ DODPC/DPPC was estimated to be 10-14 and 1115, respectively. Figure $\mathbf{1 b}$ shows the curve of the polymerization conversion when DODPC/DPPC/ 

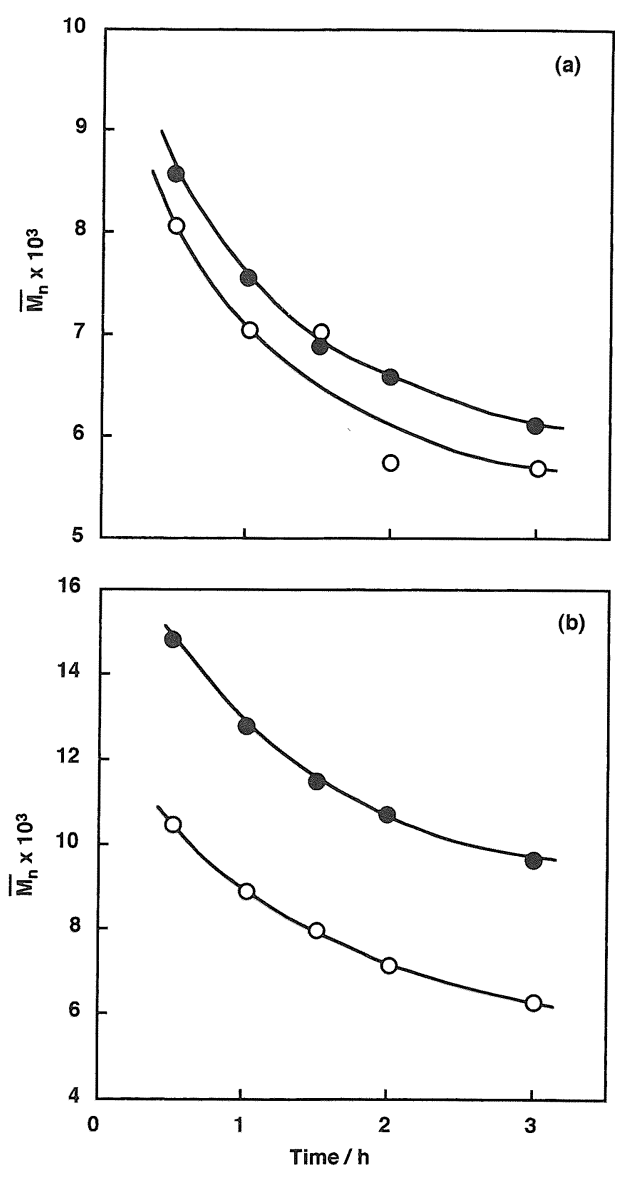

Fig. 2 Number-Average Molecular Weight as a Function of Irradiation Time for Various Conpositions of the Liposomes. Weights were Obtained from Hydrolysis of Irradiated Liposomes. (a) DODPC/DPPC Liposome, (b) DODPC/DPPC/ Chol/SA Liposome. DODPC/DPPC Molar Ratio : 10/0 (O) and 5/5 (O).

Chol/SA was $\gamma$-irradiated at a dose rate of 3.3 $\mathrm{kGy} / \mathrm{h}$. The conversions of $7 / 3$ and 5/5 DODPC/ $\mathrm{DPPC} / \mathrm{Chol} / \mathrm{SA}$ at the same dose rate were higher than those of other DPPC molar ratios, and increased with an increase in DPPC molar ratio. At corresponding molar ratios, DODPC/DPPC/ $\mathrm{Chol} / \mathrm{SA}$ liposomes had a higher conversion than DODPC/DPPC liposomes (2-15\%). Figure $2 \mathrm{~b}$ shows the $M_{n}$ of poly-2,4-octadecadienoic acids that were obtained by hydrolysis of irradiated 10/0 and 5/5 DODPC/DPPC/Chol/SA. The estimated $\mathrm{M}_{\mathbf{n}}$ of poly-2,4-octadecadienoic acids for each molar ratio decreased with an increase in irradiation time. The estimated degree of polymerization for the DODPC/DPPC/Chol/SA liposomes at a molar ratio $5 / 5$ of DODPC/DPPC was $18 \sim 26$, higher than that at 10/0 (11 19). At corresponding molar ratios, the estimated degree of polymerization of the poly-2,4-octadecadienoic acids of DODPC/DPPC/Chol/SA liposomes was higher than that of DODPC/DPPC liposomes (i.e., 10-30\% higher for molar ratio $10 / 0$ and $60-$ $70 \%$ higher for molar ratio $5 / 5$ ).

\section{$3 \cdot 2$ Stability of Mixed Liposomes}

Figures $\mathbf{3} \mathbf{a}$ and $\mathbf{3} \mathbf{b}$ show the changes in the mean diameter of $\gamma$-ray-induced polymerized DODPC/ DPPC and DODPC/DPPC/Chol/SA liposomes, respectively (irradiated for $3 \mathrm{~h}$ at a dose rate of $3.3 \mathrm{kGy} / \mathrm{h}$ ), before and after a freeze-thaw cycle. For the DODPC/DPPC liposomes, the mean diameter after one freeze-thaw cycle remained unchanged for molar ratios from 10/0 to $8 / 2$. The mean diameter for $7 / 3$ and $5 / 5$ DODPC/ DPPC after one freeze-thaw cycle increased by about $2 \%$ and $4 \%$, respectively. The stability of the DODPC/DPPC liposomes decreased with an increase in the DPPC content. On the other hand, the mean diameter of the DODPC/DPPC/Chol/SA liposomes remained relatively unchanged for the molar ratios $10 / 0,9 / 1$, and $8 / 2$ (about $1 \%$ ). For the molar ratios $7 / 3$, the mean diameter of the liposome increased $12 \%$. For the molar ratio $5 / 5$, the mean diameter dramatically changed due to a collapse of the vesicles. Although the mean diameter was about $780 \mathrm{~nm}$ with a broad size distribution, the liposome solution became a turbid suspension due to either the aggregation or fusion of the particles.

\section{Discussion}

\subsection{Polymerization of DODPC/DPPC Lipo- somes}

Our previous report on $\gamma$-ray-induced polymerization of DODPC liposomes at low temperature (e.g., $\left.4{ }^{\circ} \mathrm{C}\right)^{15}$ showed three key findings. The first was that the two acyl-chains of DODPC are polymerized independently, where the 2-acyl chain of DODPC polymerized first and then the 1-acyl chain of DODPC. The second was that the difference in reactivity can be explained by the decrease in an initiation of polymerization because the diffusion of the hydroxyl radical is the ratedetermining step during $\gamma$-ray-induced polymerization. The third was that the rate of polymerization 

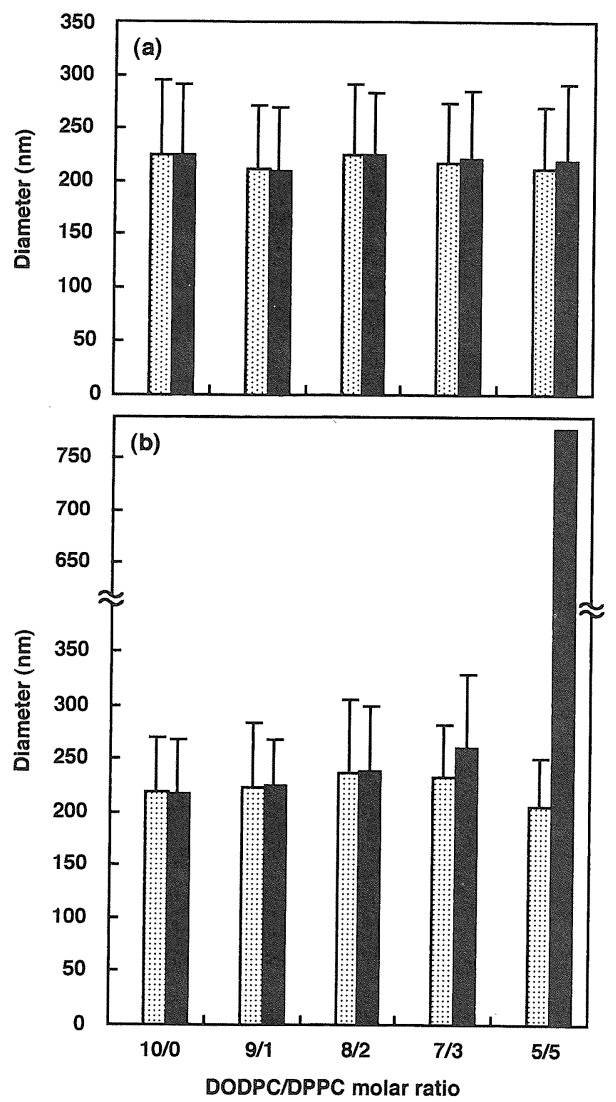

Fig. 3 Changes in Mean Diameter before and after a Freeze-Thaw Cycle for Various Molar Ratios of DODPC/DPPC Liposomes. Error Bar Represents the Standard Deviation of the Mean Diameter. (a) DODPC/DPPC Liposome, (b) DODPC/DPPC/Chol/SA Liposome. Before a Freeze-Thaw Cycle (圆) and after a FreezeThaw Cycle (圆).

is proportional to the first-order of the dose rate for each acyl chain ${ }^{15}$. The mechanism for $\gamma$-rayinduced polymerization of DODPC liposomes can be derived from a kinetic treatment of polymerization, which involves four steps (initiation, propagation, termination, chain transfer) as described in the following elementary reactions ${ }^{17}$.

Initiation

$$
\begin{aligned}
& \mathrm{H}_{2} \mathrm{O} \stackrel{k_{d i}}{\longrightarrow} \mathrm{H} \cdot+\cdot \mathrm{OH} \\
& R_{d}=k_{d i} \rho_{\mathrm{H}_{2} \mathrm{O}} \mathrm{I} \\
& \mathrm{H} \cdot+\cdot \mathrm{OH} \stackrel{k_{d t}}{\longrightarrow} \mathrm{H}_{2} \mathrm{O} \\
& R_{d t}=k_{d t}[\mathrm{H} \cdot][\cdot \mathrm{OH}]
\end{aligned}
$$

$$
\begin{aligned}
& \cdot \mathrm{OH}+\mathrm{M} \stackrel{k_{i}}{\longrightarrow} \mathrm{R} \cdot \\
& R_{i}=k_{i}[\cdot \mathrm{OH}][\mathrm{M}]
\end{aligned}
$$

Propagation

$$
\begin{aligned}
& \mathrm{R} \cdot+\mathrm{M} \stackrel{k_{p}}{\longrightarrow} \mathrm{R}_{\mathrm{n}} \cdot \\
& \mathrm{R}_{\mathrm{n}} \cdot+\mathrm{M} \stackrel{k_{p}}{\longrightarrow} \mathrm{R}_{\mathrm{n}+1} \cdot \\
& R_{p}=k_{p}\left[\mathrm{R}_{\mathrm{n}} \cdot\right][\mathrm{M}]
\end{aligned}
$$

Termination

$$
\begin{aligned}
& \mathrm{R}_{\mathrm{n}} \cdot+\mathrm{Z} \stackrel{k_{t}}{\longrightarrow} \mathrm{P}_{\mathrm{n}} \\
& R_{t}=k_{t}\left[\mathrm{R}_{\mathrm{n}} \cdot\right][\mathrm{Z}]
\end{aligned}
$$

Chain Transfer

$$
\begin{aligned}
& \mathrm{R}_{\mathrm{n}} \cdot+\mathrm{M} \stackrel{k_{t r}}{\longrightarrow} \mathrm{P}_{\mathrm{n}}+\mathrm{R} \cdot \\
& R_{t r}=k_{t r}\left[\mathrm{R}_{\mathrm{n}} \cdot\right][\mathrm{M}]
\end{aligned}
$$

where $\mathrm{M}$ is the monomer ; $\mathrm{R} \cdot$ is the monomeric active radical; $R_{n} \cdot$ is the growing radical ; $Z$ is a substance by which $\mathrm{R}_{\mathrm{n}}$ is deactivated ; $R_{d}, R_{d t}$, $R_{i}, R_{p}, R_{t}$, and $R_{t r}$ denote the rate of radical formation from the water, its reverse reaction, initiation, propagation, termination, and chain transfer, respectively, whose corresponding rate constants are $k_{d i}, k_{d t}, k_{i}, k_{p}, k_{t}$, and $k_{t r}$, respectively ; $\rho_{\mathrm{H}_{2} \mathrm{O}}$ is the density of water ; and $I$ is the dose rate.

From eqs. 1 and 2

$$
\begin{aligned}
& {[\cdot \mathrm{OH}]=\frac{k_{d i} \rho_{\mathrm{H}_{2} \mathrm{O}} I}{k_{d t}[\mathrm{H} \cdot]}=K I} \\
& \text { where } K=\frac{k_{d i} \rho_{\mathrm{H}_{2} \mathrm{O}}}{k_{d t}[\mathrm{H} \cdot]}
\end{aligned}
$$

If the initiation rate equals the termination rate (i.e., $R_{i}=R_{t}$ ), then eqs. 3, 5, and 7 yield

$$
\left[\mathrm{R}_{\mathrm{n}} \cdot\right]=\frac{k_{i} K I}{k_{t}[\mathrm{Z}]}[\mathrm{M}]
$$

Equation 4 can then be written as follows.

$$
R_{p}=-\frac{d[\mathrm{M}]}{d t}=k_{p} \frac{k_{i} K I}{k_{t}[\mathrm{Z}]}[\mathrm{M}]^{2}
$$

where $k_{p} k_{i} K I / k_{t}[\mathrm{Z}]$ represents the overall polymerization rate constant.

From this equation, the relationship between monomer concentration and irradiation time can be expressed as follows.

$$
\frac{1}{[\mathrm{M}]_{\mathrm{t}}}=k_{p} \frac{k_{i} K I}{k_{t}[\mathrm{Z}]} t+\frac{1}{[\mathrm{M}]_{0}}
$$

where $[\mathrm{M}]_{0}$ and $[\mathrm{M}]_{\mathrm{t}}$ are the monomer concentrations at time 0 and $t$, respectively.

If the termination is first-order, the degree of polymerization $\left(\mathrm{P}_{\mathrm{n}}\right)$ can be expressed as follows. 


$$
\overline{\mathrm{P}_{\mathrm{n}}}=\frac{\int_{0}^{t} R_{p} d t}{\int_{0}^{t} R_{i} d t+\int_{0}^{t} R_{t r} d t}
$$

From eqs. 4 to 6 , eq. 12 can be expressed as a function of the degree of polymerization and monomer concentration :

$$
\frac{1}{\overline{\mathrm{P}_{\mathrm{n}}}}=\frac{k_{t}[\mathrm{Z}]}{k_{p}} \cdot \frac{1}{\mathrm{M}_{\mathrm{p}}} \int_{0}^{t} \frac{R_{p}}{[\mathrm{M}]} d t+\frac{k_{t r}}{k_{p}}
$$

where $\mathrm{M}_{\mathrm{p}}=\int_{0}^{t} R_{p} d t$ and is the concentration of consumed monomer till at within time t.

As we have previously reported for the $\gamma$-rayinduced polymerization of pure DODPC liposomes, the conversion increased to $50 \%$, and then increased more slowly with further irradiation. Therefore, we designated the polymerization below conversion of $50 \%$ as region $\mathrm{I}$, and that above $50 \%$ as region $\mathrm{II}^{177}$. When eq. 11 was applied to each region as a monomer concentration of $100 \%$, a linear relationship was obtained for each region. However, when no distinction was made between regions I and II, i.e., the monomer concentration was estimated as $100 \%$ for both regions, no linear relationship was obtained. Twostep polymerization reasonably explains the behavior of the polymerization of DODPC liposomes, where the conversion slowly increased at around $60 \sim 70 \%$; the polymerization rate above a conversion of $50 \%$ was slower than that below a conversion of $50 \%$.

We analyzed the $\gamma$-ray-induced polymerization of DODPC/DPPC liposomes based on the results obtained from the polymerization of DODPC liposomes. The shape of the polymerization conversion curves for all DODPC/DPPC liposomes, irrespective of molar ratio, were similar to the pure DODPC liposomes as shown in Fig. 1a. As we did for the pure DODPC liposome, we applied eq. 11 to various molar ratios of DODPC/ DPPC liposomes. Region I showed a linear relationship between the inverse of monomer concentration and irradiation time, and had an intercept of 1 (Fig. 4a). For every molar ratio, region II also showed a linear relationship with an induction period. This induction period is defined as the time of initiation of the second step at $50 \%$ conversion (Fig. 4b), where the time of initiation is expressed at time of $1 /[\mathrm{M}]=1$. For each region, all lines fit eq. 11, thus indicating that the
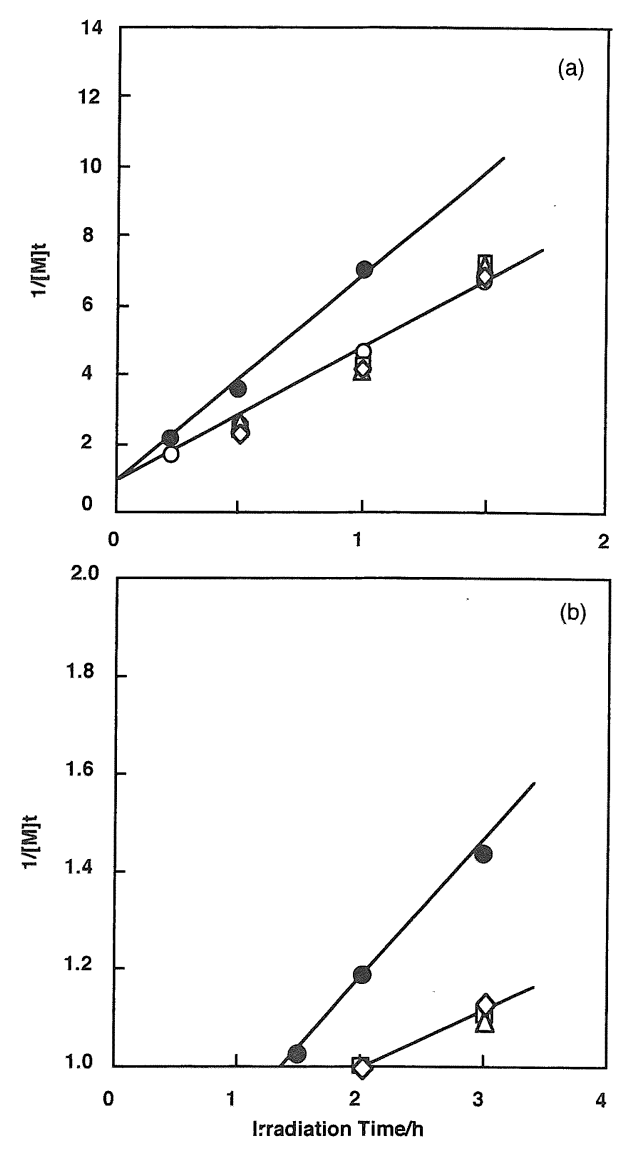

Fig. 4 Plot of $1 /[\mathrm{M}]_{\mathrm{t}}$ vs. Irradiation Time for DODPC/ DPPC Liposomes in (a) Region I and (b) Region II. DODPC/DPPC Molar Ratio : 10/0 $(\bigcirc), 9 / 1(\diamond), 8 / 2(\triangle), 7 / 3(\square)$, and $5 / 5(\bigcirc)$.

polymerization of the DODPC/DPPC liposomes involves the same mechanism as that of the pure DODPC liposomes. The slopes of these lines denote the overall polymerization rate constant $\left(k_{p} k_{i} K I / k_{t}[\mathrm{Z}]\right)$, and are listed in Table 1 for various molar ratios and for each region. For region I, the slopes for the DODPC/DPPC liposomes were similar, except for 5/5 DODPC/ DPPC, whose slope was about 1.4 times greater. For region II, the polymerization rate of $5 / 5$ DODPC/DPPC was about 2.6 times greater than that at of DODPC/DPPC at other molar ratios. The increased value in $k_{p} k_{i} K I / k_{t}[\mathrm{Z}]$ for region II was higher than that for region I. This result indicates that the 1-acyl chain (region II), which is located in the hydrophobic region, is easily affected by the addition of DPPC. Ohno et al. 
Table 1 The Overall Polymerization Rate Constant for $\gamma$-Ray Polymerization of Mixed-Liposome Systems at $4^{\circ} \mathrm{C}$.

\begin{tabular}{lccc}
\hline \multirow{2}{*}{ mixed-liposomes system } & $\begin{array}{c}\text { molar ratio } \\
\text { (DODPC/DPPC) }\end{array}$ & \multicolumn{2}{c}{$\begin{array}{c}\text { overall polymerization rate constant } \\
k_{p} k_{i} K I / k_{t}[\mathrm{Z}]\end{array}$} \\
\cline { 3 - 4 } & & Region I $^{\text {b) }}$ & Region II $^{\text {b) }}$ \\
\hline DODPC/DPPC & $10 / 0$ & 3.9 & 0.11 \\
& $9 / 1$ & 3.9 & 0.11 \\
& $8 / 2$ & 3.9 & 0.11 \\
DODPC/DPPC/Chol/SA & $7 / 3$ & 3.9 & 0.11 \\
& $5 / 5$ & 5.6 & 0.28 \\
& $10 / 0$ & 4.6 & 0.18 \\
& $9 / 1$ & 4.6 & 0.25 \\
& $8 / 2$ & 4.6 & 0.27 \\
& $7 / 3$ & 7.0 & 0.39 \\
& $5 / 5$ & 10.7 & 0.40 \\
\hline
\end{tabular}

a) the slope from plots of eq 11 .

b) Region I and II are designated as the polymerization conversion below and above $50 \%$, respectively.

studied the unequivalent chemical environment of the 2,4-diene groups in 1-acyl chains and 2-acyl chains of DODPC liposomes and found that the 1and 2-acyl chains are located in the hydrophobic region and hydrophilic region, respectively ${ }^{18)}$. Therefore, we assigned regions I and II to the 2and 1-acyl chains, respectively, due to the hydroxyl radicals generated in a hydrophilic region.

Figure 5 shows the relationship between the inverse of $\mathrm{P}_{\mathrm{n}}$ and the function of monomer concentration. The slope $\left(k_{t}[\mathrm{Z}] / k_{p}\right)$ and intercept $\left(k_{t r} / k_{p}\right)$ of each line are summarized in Table 2. The slope of the line for 5/5 DODPC/DPPC was $3.1 \times 10^{-2}$, about 1.4 times smaller than that for $10 / 0$ DODPC/DPPC. This decrease in slope is due to the 1.4-fold increase in $k_{p}$, because the slope is expressed as $k_{t}[\mathrm{Z}] / k_{p}$ in eq. 13 . By using eq. 13 , we also derived the increase in $k_{p}$. Furthermore, the intercept of eq. 13 denotes $k_{t r} / k_{p}$. Although the $k_{t r} / k_{p}$ for 5/5 DODPC/DPPC was the same as that for $10 / 0$ DODPC/DPPC, the $k_{p}$ for 5/5 DODPC/ DPPC was also larger than that for $10 / 0 \mathrm{DODPC} /$ DPPC. This finding indicates that $k_{t r}$ also increases with an increase in $k_{p}$ by the addition of DPPC in bilayer membranes. For the DODPC/DPPC liposomes, our results show that both the rate of propagation and chain transfer increased when DPPC was added to DODPC at an equimolar ratio. Therefore, this increase explains the observed increase in both the rate of polymerization and the degree of polymerization. Generally,

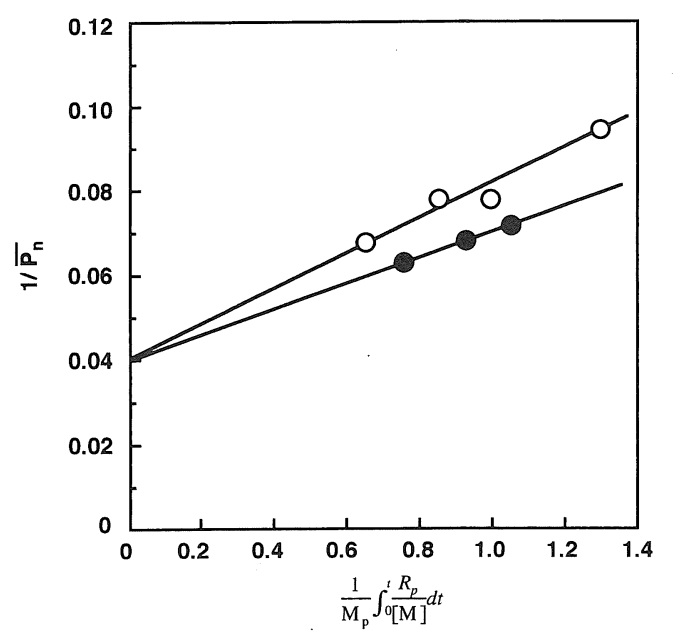

Fig. 5 Plot of $1 / \overline{\mathrm{P}}$ vs. $1 / \mathrm{M}_{\mathrm{P}} \cdot \int_{0}^{t}\left(R_{p} /[\mathrm{M}]\right)_{d t}$ for DODPC/ DPPC Liposomes. DODPC/DPPC Molar Ratio : 10/0 (○) and $5 / 5(\bigcirc)$.

an increase in $k_{t r}$ caused a decrease in the molecular weight, except for 5/5 DODPC/DPPC, where it caused a slight increase due to an increase in $k_{p}$ rather than in $k_{t r}$.

If the polymerizable phospholipids were completely miscible with the unpolymerizable substances, then according to eq. 10, the polymerization rate $\left(R_{p}\right)$ would decrease as the concentration of polymerizable phospholipids decreased (i.e., monomer concentration decreased) in the bilayer 
Table 2 The Parameter of Kinetics for $\gamma$-Ray Polymerization of Mixed-Liposome Systems at $4^{\circ} \mathrm{C}$.

\begin{tabular}{|c|c|c|c|c|c|}
\hline \multirow[t]{2}{*}{ mixed-liposomes system } & \multirow{2}{*}{$\begin{array}{l}\text { molar ratio } \\
\text { (DODPC/DPPC) }\end{array}$} & \multicolumn{2}{|c|}{$\begin{array}{c}\text { slope }^{\mathrm{a})} \\
k_{t}[\mathrm{Z}] / k_{p}\left(\mathrm{x} 10^{-2}\right)\end{array}$} & \multicolumn{2}{|c|}{ 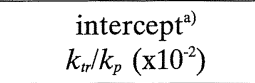 } \\
\hline & & Region I & Region II & Region I & Region II \\
\hline \multirow{2}{*}{ DODPC/DPPC } & $10 / 0$ & 4.2 & - & 4.0 & - \\
\hline & $5 / 5$ & 3.1 & - & 4.0 & - \\
\hline \multirow{2}{*}{ DODPC/DPPC/Chol/SA } & $10 / 0$ & 5.1 & 16.7 & 1.6 & 0.67 \\
\hline & $5 / 5$ & 2.2 & 7.4 & 1.6 & 0.67 \\
\hline
\end{tabular}

a) derivate from eq 13 .

membranes. However, $R_{p}$ for the DODPC/DPPC liposomes at a molar ratio of $5 / 5$ was higher than that at $10 / 0$ under the same polymerization conditions. The concentration of the hydroxyl radical reacting with DODPC as the initiator did not decrease with increasing mole fraction of DODPC. The reason is that hydroxyl radicals are constantly generated during $\gamma$-irradiation at the same dose rate (i.e., $k_{i} K I / k_{t}[\mathrm{Z}]$ in eq. 10 is assumed constant, irrespective of mole fraction of DPPC). Therefore, the increase in $k_{p} k_{i} K I / k_{t}[\mathrm{Z}]$ due to increasing mole fraction of DPPC was caused by the increase in $k_{p}$. Furthermore, these results indicate that DODPC is not completely miscible with DPPC in the bilayer membranes. This immiscibility means that each phospholipid exists in its own "domain". The domain structure of polymerizable lipids and unpolymerizable lipids in a bilayer membrane is well known and has been studied in recent years ${ }^{19), 20)}$. Tsuchida et al. clarified the domain structure for DODPC and DPPC mixed-liposome systems by using scanning electron microscopy and various techniques (e.g., differential scanning calorimetry and fluorescence measurements) ${ }^{21}$.

Our results showing increases in both $\mathrm{P}_{\mathrm{n}}$ and $k_{p}$ also clarify the domain structure of DODPC and DPPC, because DODPC may be immiscible with DPPC in bilayer membranes and thus leads to a kinetic treatment of polymerization. Not only do DODPC molecules form a domain structure but also the DODPC molecules in the domain structure in bilayer membranes may be stacked and arranged for easy polymerization, because the hydrophobic acyl chain of DPPC in DPPC domains interact with the polymerizable acyl chain of DODPC in DODPC domains. Consequently, the conformation of DODPC molecules may change to one for easy polymerization. Therefore, $k_{p}$ of the DODPC/DPPC liposomes was higher than that for pure DODPC liposomes. In the interaction between DODPC and DPPC, the hydrophobic interaction of the acyl chain of DPPC may be stronger for the 1-acyl chain of DODPC located in the hydrophobic region than for the 2acyl chain that faces the hydrophilic region.

For the interaction between DODPC and DPPC in the DODPC/DPPC liposomes, Takeoka et al. reported changes in the wavelength of DODPC for different mole fractions of DPPC ${ }^{22}$. They found that for a DPPC mole fraction above about $0.7 \sim$ 0.8 , the change in the difference of $\lambda_{\max }$ is similar above $T_{c}$ and below $T_{c}$, and that for a DPPC mole fraction of 0.5 , the change in the difference of $\lambda_{\max }$ is significantly lower than that at higher mole fractions. This behavior suggests that interaction between DODPC and DPPC changes at a molar ratio of 0.5 . This finding agrees with our results that $k_{p}$ increased when the molar ratio was $5 / 5$.

$4 \cdot 2$ Polymerization of DODPC/DPPC/Chol/ SA Liposomes

The kinetic treatment of polymerization was applied similarly to both the DODPC/DPPC liposomes and pure DODPC liposomes. For region $\mathrm{I}$, a plot of the irradiation time versus the inverse of the monomer concentration (eq. 11) of DODPC for various molar ratios of DODPC/ DPPC (Fig. 6a) shows a straight line whose intercept is 1 . The $7 / 3$ and $5 / 5$ DODPC/DPPC/ $\mathrm{Chol} / \mathrm{SA}$ had slopes that were 1.5 and 2.3 times greater, respectively, than those for DODPC/ $\mathrm{DPPC} / \mathrm{Chol} / \mathrm{SA}$ at the other molar ratios. For region II, a similar plot of eq. 11 shows a linear relationship with an induction period, which signals the second step in the polymerization. These results indicate that the mechanism of the $\gamma$ - 

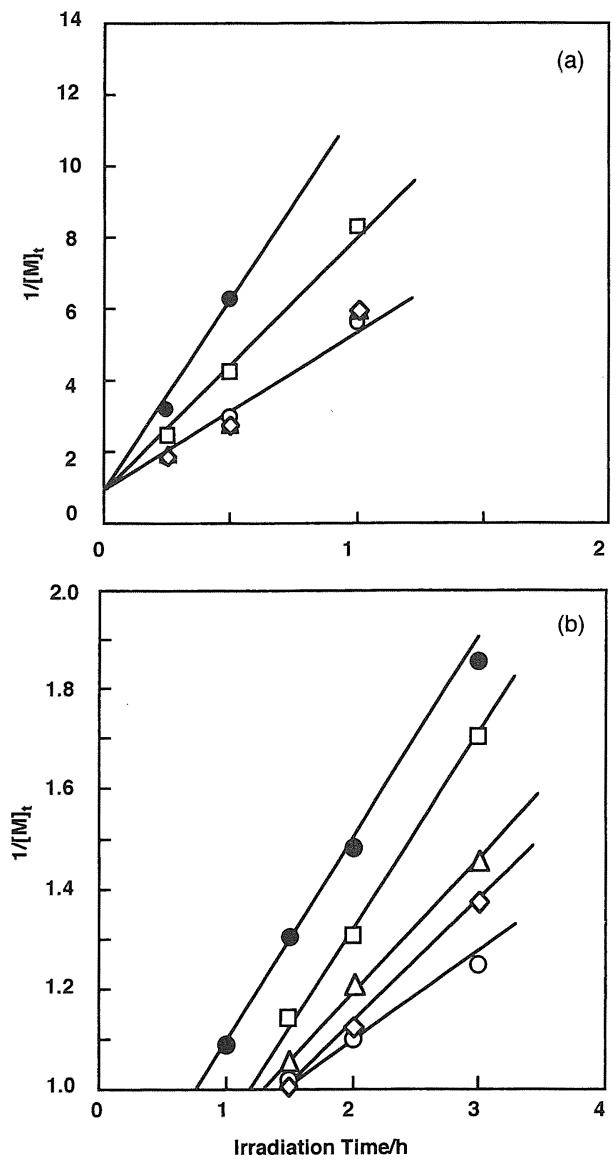

Fig. 6 Plot of $1 /[\mathrm{M}]_{\mathrm{t}}$ vs. Irradiation Time for DODPC/ DPPC/Chol/SA Liposome in (a) Region I and (b) Region II. DODPC/DPPC Molar Ratio : 10/0 (○), $9 / 1(\diamond), 8 / 2(\triangle), 7 / 3(\square)$, and $5 / 5(\bigcirc)$.

ray-induced polymerization in the DODPC/DPPC/ $\mathrm{Chol} / \mathrm{SA}$ liposomes is similar to that in the pure DODPC liposomes and DODPC/ DPPC liposomes, although $k_{p}$ is greater than the corresponding molar ratio of DODPC/DPPC liposomes. Figure 7 shows plots of the overall polymerization rate constant, $k_{p} k_{i} K I / k_{t}[\mathrm{Z}]$, versus the mole fraction of DODPC for each region. For region I, the $k_{p} k_{i} K I / k_{t}[\mathrm{Z}]$ did not change until the DODPC/DPPC molar ratio reached 8/2 (0.35 DODPC mole fraction), and then increased with an increase in the DPPC molar ratio. For region II, the $k_{p} k_{i} K I / k_{t}[\mathrm{Z}]$ linearly increased with an increase in the DPPC molar ratio. In other words, first the 1-acyl chain of DODPC, which is located in a hydrophobic region, is initially affected by the
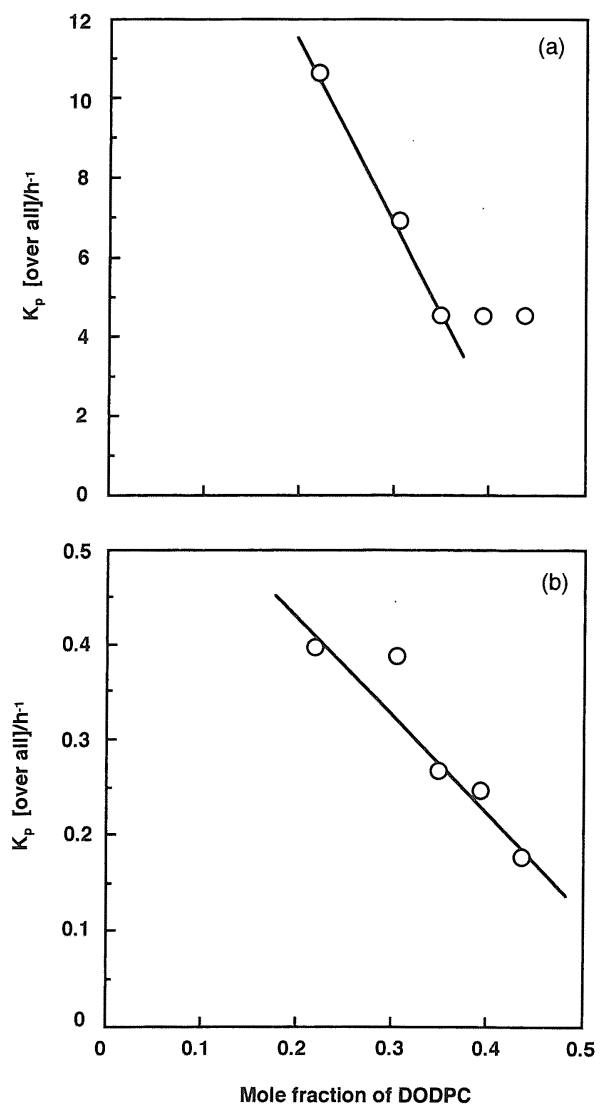

Fig. 7 Dependence of the Overall Polymerization Rate Constant and Mole Fraction of DODPC in the DODPC/DPPC/Chol/SA Liposomes in (a) Region I and (b) Region II.

increase in DPPC, and then the 2-acyl chain is affected by the addition of $0.3 \mathrm{DPPC}$ mole fraction to DODPC. This two-step behavior might be because the 1-acyl chain is affected by the hydrophobic interaction of the acyl chain of DPPC, and is thus changed to an easily polymerizable conformation.

From the viewpoint of the reaction kinetics, the polymerization rate $\left(R_{p}\right)$ of the DODPC/DPPC/ Chol/SA liposomes expressed by eq. 10 was similar to that of the DODPC/DPPC liposomes. If the DODPC and unpolymerizable lipids are completely miscible with each other, then the decrease in $R_{p}$ is due to the decrease in DODPC concentration as described in the previous section (Polymerization of DODPC/DPPC liposomes). The $R_{p}$ for the cholesterol-mixed system, however, increased with increasing DPPC content in the membrane. This 
content-related increase in $R_{p}$ was greater for DODPC/DPPC/Chol/SA liposomes than that for the DODPC/DPPC liposome. This means that the cholesterol-mixed system also creates a domain structure between the DODPC and the unpolymerized components, such as DPPC and Chol.

Figure 8 shows plots of the inverse of $P_{n}$ versus the function of monomer concentration for each region for both $10 / 0$ and 5/5 DODPC/DPPC/ $\mathrm{Chol} / \mathrm{SA}$. For each region and each molar ratio, the plots show a linear relationship with a positive intercept. The intercept of region I and II are about $1.6 \times 10^{-2}$ and $0.67 \times 10^{-2}$, respectively. The slope and intercept when plot eq. 13 are listed in Table 2. For each region, the slope of the line for 5/5 DODPC/DPPC/Chol/SA was less than that for $10 / 0$ DODPC/DPPC/Chol/SA. This decrease in the $k_{t}[\mathrm{Z}] / k_{p}$ was due to the increase in $k_{p}$. These results agree with the results seen in the plot of eq. 11 (Fig. 6). The $k_{t r} / k_{p}$ was similar for both $10 / 0$ and 5/5 DODPC/DPPC (Fig. 8). This unchanged $k_{t r} / k_{p}$ indicates that $k_{t r}$ increases with an increase in $k_{p}$. However, an increase in $k_{p}$ reflects molecular weight more than does an increase in $k_{t r}$ in this system because the molecular weight for $5 / 5$ DODPC/DPPC/Chol/SA was larger than that for 10/0 DODPC/DPPC/Chol/SA. Although the in-

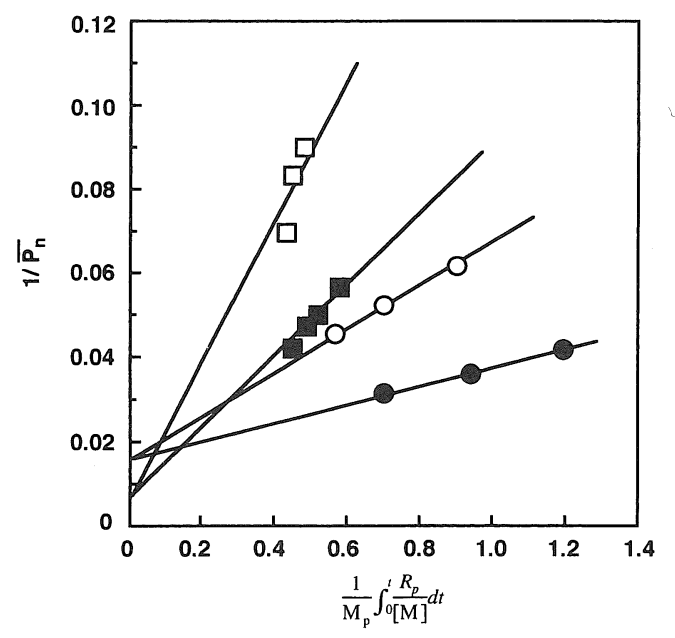

Fig. 8 Plot of $1 / \overline{\mathrm{P}}$ vs. $1 / \mathrm{M}_{\mathrm{p}} \cdot \int_{0}^{t}\left(R_{p} /[\mathrm{M}]\right) d t$ for DODPC/DPPC/Chol/SA Liposomes. Rigion I of DODPC/DPPC Molar Ratio : 10/0 (O) and 5/5 (O), Rigion II of DODPC/DPPC Molar Ratio : 10/0 ( $\square)$ and $5 / 5$ (圆). creases in both the polymerization rate and the molecular weight of the DODPC/DPPC/Chol/SA liposomes were higher than those of the DODPC/ DPPC liposomes, the $\gamma$-ray-induced polymerization of DODPC/DPPC/Chol/SA liposome proceeds by the same mechanism as that of the pure DODPC liposomes.

The effect of adding Chol and SA to DODPC liposome membranes can be determined by comparing the $k_{t}[\mathrm{Z}] / k_{p}$ and $k_{t r} / k_{p}$ for each DODPC/DPPC and DODPC/DPPC/Chol/SA liposomes for a DODPC/DPPC molar ratio of 10/0 (Table 2 ) ; i.e., DODPC and DODPC/Chol/SA liposomes. The $k_{t r} / k_{p}$ of DODPC liposome (4.0 $\times$ $10^{-2}$ ) was about 2.5 times larger than that for the $\mathrm{DODPC} / \mathrm{Chol} / \mathrm{SA}$ liposomes for Region I, which is the 2-acyl chains $\left(1.6 \times 10^{-2}\right)$. The $k_{p}$ of the DODPC/Chol/SA liposomes was about 1.5 times larger than that of DODPC liposomes, due to an increase in $k_{p} k_{i} K I / k_{t}[\mathrm{Z}]$ attributed to an increase in $k_{p}$. Therefore, the $k_{t r}$ of the DODPC/Chol/SA liposomes was lower than that of the DODPC liposomes. Consequently, the observed increase in the molecular weight of the DODPC/Chol/SA liposomes is explained by the decrease in the rate of chain transfer and by the increase in the propagation rate. When Chol and SA are added to DODPC bilayer membranes, the acyl chain of the polymerizable phospholipids may be affected by a strong hydrophobic interaction between $\mathrm{Chol}$ and $\mathrm{SA}$, and thus can rearrange itself into an easily polymerizable conformation. Although $\mathrm{Chol}$ and SA enhance the propagation by hydrophobic interaction, they do not enhance the chain transfer.

Our results yield three key findings. First, both the DODPC/DPPC liposomes and the DODPC/ $\mathrm{DPPC} / \mathrm{Chol} / \mathrm{SA}$ liposomes used the same polymerization mechanism as that previously reported for DODPC liposomes ${ }^{15}$. Second, for equimolar ratios of DPPC added to DODPC liposomes, the increase in both $k_{p}$ and $k_{t r}$ caused a slight increase in the molecular weight. Third, the addition of Chol and SA to pure DODPC liposomes caused an increase in $k_{p}$ and a decrease in $k_{t r}$. The effect of adding DPPC to the DODPC/Chol/SA liposomes on the molecular weight was greater than the effect of adding DPPC to the pure DODPC liposomes, because the decrease in chain transfer for DODPC/DPPC/Chol/SA liposomes is greater than 
that for DODPC/DPPC liposomes.

4.3 Stability of the Mixed Liposomes

For the DODPC liposomes and the DODPC/ DPPC liposomes, a freeze-thaw cycle induced a slight change in the mean diameter of the polymerized equimolar DODPC/DPPC liposomes. After polymerization, the DODPC polymer content of 10/0 and 5/5 DODPC/DPPC was $55 \%$ and $33 \%$, respectively, because the respective polymerization conversions were about $55 \%$ and $65 \%$. The irradiated 5/5 DODPC/DPPC liposomes, whose DODPC polymer was at $33 \%$ and average degree of polymerization was about 11 , cannot completely withstand a freeze-thaw cycle. For the DODPC/DPPC/Chol/SA liposomes, a freeze-thaw cycle induced no change in the mean diameter, even for the irradiated $8 / 2$ DODPC/ DPPC/Chol/SA. The DODPC polymer at that molar ratio was $22 \%$ because the mole fraction of DODPC was 0.35 and conversion was $65 \%$. Although the DODPC polymer and conversion for this ratio were less than that for 5/5 DODPC/ DPPC, the stability was greater than that for DODPC/DPPC liposomes due to a higher degree of polymerization. However, the $5 / 5 \mathrm{DODPC} /$ DPPC/Chol/SA, whose DODPC polymer was about $16 \%$ and degree of polymerization was 18 , can not survive as a vesicle. Our results show that the relationship between DODPC polymer and degree of polymerization are an important factor in stabilizing the liposome by polymerization.

\section{Conclusion}

Two mixed-liposome systems, DODPC/DPPC and DODPC/DPPC/Chol/SA liposomes, were polymerized by using $\gamma$-ray irradiation. The polymerization behavior of both systems involved the same mechanism as that of DODPC liposomes by using a kinetic treatment of polymerization. Both the rate of polymerization and the degree of polymerization of these mixed-lipid systems were higher than that of DODPC liposomes at the same irradiation conditions and increased with increasing molar ratio of DPPC. Addition of Chol and SA to DODPC liposomes also enhanced both the rate and degree of polymerization due to increase in $k_{p}$ and decrease in $k_{t r}$. Furthermore, the immiscibility between DODPC and unpolymerizable components (e.g., DPPC and Chol) was confirmed by analyzing the kinetic treatment of polymerization.
This result suggests that the DODPC and unpolymerizable component each form their own domain at low temperature (e.g., $4{ }^{\circ} \mathrm{C}$ ). Consequently, the DODPC molecule in the DODPC domain when the molar ratio of unpolymerizable components domain in the membrane increases, can rearrange into an easily polymerizable conformation. Therefore, both the polymerization rate and molecular weight of the DODPC liposomes increased. Our results suggest that $\gamma$-ray polymerization of DODPC with unpolymerizable lipids might be significantly affected by the unpolymerizable-lipid domain in the bilayer membrane, such as the domain of DPPC and Chol. The cause of this behavior might be hydrophobic interaction of unpolymerizable lipids with the acyl chain of DODPC. The increase in the polymerization rate and molecular weight due to the addition of DPPC and/or Chol depends on the mole fraction. When an unpolymerizable component is added to a DODPC membrane, the type and molar ratio of the component are critical factors in the polymerization of DODPC.

\section{Acknowledgment}

We thank Dr. Yoshishige Murata (Tsukuba Research Laboratory, NOF Corporation) for his helpful discussions and encouragement. We express deepest regret on the death of Mr. Fumio Hosoi (March 13, 1998), whom we gratefully acknowledge.

(Received Dec. 2, 1999 ; Accepted Feb. 28, 2000)

\section{References}

1) D.A. Tirrell, L.G. Donaruma, A.B. Turek, "Macromolecules as Drugs and as Carriers for Biologically Active Materials", The New York Academy of Sciences, New York (1985).

2) C.G. Kinight, "Liposomes", Elsevier, Amsterdam (1981) p.51.

3) M.J. Ostro, "Liposomes", Marcel Dekker, Inc., New York (1983) p.289.

4) H. Ringsdorf, B. Schlarb, J. Venzmer, Angew. Chem. Int. Ed. Engl., 27, 113 (1988).

5) D.F. O'Brien, Trends. Polym. Sci., 2, 183 (1994).

6) A. Singh, J.M. Schnur, Polym. Adv. Technol., 5, 358 (1994).

7) F. Hosoi, H. Omichi, K. Akama, K. Awai, S. Endo, Y. Nakano, Nucl. Instrum. Methods. Phys. Res., Sect. B, 131, 329 (1997).

8) H. Sakai, S. Takeoka, H. Yokohama, H. Nishide, 
E. Tsuchida, Polym. Adv. Technol., 3, 389 (1992).

9) K. Akama, K. Awai, S. Tokuyama, T. Satoh, F. Hosoi, H. Omichi, Radiat. Phys. Chem., 46, 257 (1995).

10) K. Morizawa, K. Akama, Y. Kawakami, E. Tsuchida, Biomater. Artif. Cells Immobil. Biotechnol., 20, 641 (1992).

11) E. Tsuchida, H. Nishide, Biomater. Artif. Cells Immobil. Biotechnol., 19, 494 (1991).

12) K. Akama, K. Morizawa, S. Tokuyama, S. Satoh, K. Kobayashi, S. Sekiguchi, E. Tsuchida, Biomater. Artif. Cells Immobil. Biotechnol., 22, 901 (1994).

13) K. Morizawa, S. Tokuyama, K. Akama, K. Awai, T. Satoh, Jpn. J. Artif. Organs, 23, 858 (1994).

14) E. Tsuchida, E. Hasegawa, N. Kimura, M. Hatashita, C. Makino, Macromolecules, 25, 207 (1992).

15) F. Hosoi, H. Omichi, K. Akama, K. Awai, S.
Tokuyama, T. Satoh, Nucl. Instrum. Methods. Phys. Res., Sect. B, 105, 318 (1995).

16) F. Hosoi, H. Omichi, K. Akama, K. Awai, Y. Yano, Y. Nakano, J. Jpn. Oil. Chem. Soc., 47, 31 (1998).

17) K. Akama, Y. Yano, S. Tokuyama, F. Hosoi, H. Omichi, J. Materials. Chem., 10 (5), 1047 (2000).

18) H. Ohno, S. Takeoka, E. Tsuchida, Bull. Chem. Soc. Jpn., 60, 2945 (1987).

19) B.A. Armitage, D.E. Bennett, H.G. Lamparski, D.F. O'Brien, Adv. Polym. Sci., 126, 53 (1996).

20) D.E. Davies, M. Critholw, D.W. Grainger, A. Reichert, H. Ringsdorf, J.B. Lloyd, Biochim. Biophys. Acta, 1084, 29 (1991).

21) E. Tsuchida, N. Seki, H. Ohno, Makromol. Chem., 187, 1351 (1986).

22) S. Takeoka, H. Iwai, H. Ohno, E. Tsuchida, Bull. Chem. Soc. Jpn., 62, 102 (1989). 


\title{
[報文］２,4-オクタデカジエン基を有するリン脂質と
}

\section{非重合性成分からなる混合系リポソームの $\gamma$ 線重合}

赤間 和 博*1 ・粟井浩二*1 ・矢野嘉 宏*1

徳 山 悟*1 中野 善 郎 ${ }^{* 1}$ 細 井文 雄*2 $・$ 大道 英 樹*2

*1 日本油脂株式会社 筑波研究所（广 300-2635 茨城県つくば市東光台 5-10)

*2 日本原子力研究所 高崎研究所（广 370-1207 群馬県高崎市綿貫町 1233）

1,2-ビス [ $(2 E, 4 E)$ - オクタデカエイル $]$ - $s n^{-}$グリセロ -3- ホスホコリン（DODPC）を含有する混合脂質 系リポソームの $\gamma$ 線重合の重合機構解明のため，（ $a$ ） DODPC と 1,2-ジパルミトイル - sn-グリセロ-3- ホスホ コリン（DPPC）からなる DODPC/DPPCリポソーム，（b） DODPC，DPPC，コレステロール (Chol)，ステア リン酸（SA）からなる DODPC/DPPC/Chol/SA リポソームの 2 種類の混合脂質を調製し， $\gamma$ 線重合の挙動につ いて調べた。各々の系について，種々の DODPC/DPPC モル比について検討した。また， DODPC/DPPC/Chol/SA リポソームは, リン脂質/Chol/SA のモル比を 7/7/2 とした。各系のリポソームはエク ストルージョン法により孔径 $0.2 \mu \mathrm{m}$ のポリカーボネートフィルターを通過させたのち, 線量率 $3.3 \mathrm{kGy} / \mathrm{h}, 4^{\circ} \mathrm{C}$ で $\gamma$ 線照射により重合を行った。DODPC/DPPCリポソームのモル比 5/5, DODPC/DPPC/Chol/SA リポソーム のモル比 $9 / 1 ， 8 / 2 ， 7 / 3 ， 5 / 5$ において，重合速度が増加した。重合度は，いずれの系においてもモル比が $5 / 5$ のときに，DPPC を含有しない DODPCリポソームと比べ増加した。混合脂質りポソームの安定性に関しては， いずれの系もDODPC/DPPC モル比が 10/0 から 8/2 までは凍結融解操作に対する粒径変化がなかった。各系の リポソームの $\gamma$ 線照射による重合挙動を重合速度論的に解析した結果，いずれの系も重合速度の増加が見られた が，重合機構は同じであった。また，DODPC と非重合性成分は，お互いに不溶であることが示唆された。重合 速度と重合度の増加は，DPPC またはコレステロールの疎水性的な相互作用によりDODPCのコンフォメーショ ンが変化し，重合し易いように配向するためと推定された。

（連絡者：赤間和博・中野善郎） Vol.49, No.6, $591 （ 2000)$

\section{[報文 $]$}

\section{ラングミュアーブロジェット膜中での \\ 界面活性アゾ色素の配向： 赤外㧍よび紫外可視分光法による研究}

\author{
今 栄 東洋子 ${ }^{* 1, * 2}$ ・鳥 居 弘 之*2 \\ * 1 名古屋大学物質科学国際研究センター \\ * 2 名古屋大学大学院理学研究科 \\ （广 464-8602 愛知県名古屋市千種区不老町）
}

赤外透過および反射吸収スペクトルが， 5 および $30 \mathrm{mNm}^{-1}$ の表面圧で調製された界面活性アゾ色素のラング ミュアーブロジェット（LB）膜に対して測定された。LB 膜内の分子は累積圧に依存して配向することが赤外吸 収スペクトルによって示された。紫外可視吸収スペクトルにおいて，トランス配位をとるアゾ色素の吸収帯は 5 $\mathrm{mNm}^{-1}$ で調製した LB 膜ではブルーシフトし， $30 \mathrm{mNm}^{-1}$ での膜ではレッドシフトした。これはそれぞれの膜内で $\mathrm{H}$ および J 会合体が形成されたことを示唆する。LB 膜内での界面活性アゾ色素分子の配向が議論された。

(連絡者：今栄東洋子) Vol.49, No.6, 605 (2000) 